This item was submitted to Loughborough's Research Repository by the author.

Items in Figshare are protected by copyright, with all rights reserved, unless otherwise indicated.

\title{
Sponsorship and advertising in sport: a study of consumers' attitude
}

PLEASE CITE THE PUBLISHED VERSION

https://doi.org/10.1080/16184742.2018.1517271

PUBLISHER

(c) European Association for Sport Management. Published by Taylor \& Francis (Routledge)

VERSION

AM (Accepted Manuscript)

PUBLISHER STATEMENT

This is an Accepted Manuscript of an article published by Taylor \& Francis in European Sport Management Quarterly on 25 September 2018, available online:

http://www.tandfonline.com/10.1080/16184742.2018.1517271.

\section{LICENCE}

CC BY-NC-ND 4.0

\section{REPOSITORY RECORD}

Cheong, Cherie, Do Young Pyun, and Ho Keat Leng. 2018. "Sponsorship and Advertising in Sport: A Study of Consumers' Attitude". figshare. https://hdl.handle.net/2134/34712. 
1 Running Head: Sport Sponsorship and Advertising through Sport

2

3

4

5

6

7

8

Sponsorship and Advertising in Sport: A Study of Consumers' Attitude

9

10

11

12

13

14

15

16

17

18

19 


\section{Abstract}

2 Research question: Advertising has been considered a less efficient vehicle of marketing

3 communication. One recent study refuted that unlike traditional adverting mediums,

4 consumers' attitude towards advertising was rather favourable in sport. This study compared

5 consumers' attitudes between advertising and sponsorship in sport and examined the

6 antecedents (beliefs) and consequence (purchase intentions) of attitude in advertising and

7 sponsorship.

8 Research methods: Data were collected from 324 consumers. For testing of psychometric

9 properties of the measures, a confirmatory factor analysis and a multiple invariance test were 10 employed. A paired t-test, structural equation modeling, and invariance tests were conducted 11 to test the research hypotheses.

12 Results and Findings: There was no significant difference in consumers' attitudes between

13 advertising and sponsorship which were both deemed favourable. The path analyses revealed

14 two positive beliefs (product information and hedonism/pleasure) and one negative belief

15 (falsity/no sense) as significant predictors of attitude in both models. Good for the economy

16 was an additional significant predictor of attitude in advertising but it was not so in

17 sponsorship. The strengths of the three path coefficients were statistically identical across the two models. Attitude was a significant indicator of purchase intentions in both models; however, the invariance test revealed that the path in adverting was statistically stronger than 20 that in sponsorship.

21 Implications: This study provides important knowledge about consumers' cognitive structures that could explain their decision making processes. Sport marketers could develop

23 their promotion strategies more successfully, conveying their intent in a manner consistent

24 with positive beliefs and avoiding activating negative beliefs.

25 Keywords: advertising through sport, sport sponsorship, belief, attitude, purchase intentions 


\section{Introduction}

2 With greater emphasis and focus now placed on sport promotions, the global market sees the

3 rapid rise of sport promotion as a major component of the marketing mix (Schwarz, Hunter,

4 \& Lafleur, 2013). This study explores two pivotal components in the sport promotion mix -

5 advertising and sponsorship, where sport functions as an independent advertising or

6 sponsorship platform. Advertising through sport may include any type of advertising using

7 traditional mediums (e.g., television, print, online) but utilise sport-related contents as a

8 natural advertising platform (Pyun \& James, 2011). The term of sport-related contents

9 includes all types of sporting amateur or professional events, athletes/coaches, teams, sport

10 scenes and the like (Pyun \& James, 2011). Advertising through sport may also include the

11 presence of advertising at a sporting event such as in-stadium signage at games (Pyun, Kwon,

12 Chon, \& Han, 2012). When attending a football game at the stadium, consumers may be

13 exposed to different types of signage. Unlike other traditional advertising mediums, one

14 unique characteristic of advertising through sport is that people unconsciously experience

15 such advertisements because they visit stadiums to watch sporting actions rather than the ads

16 (Harshaw \& Turner, 1999). It should be noted that while such in-stadium is sometimes

17 considered as sponsorship as it is often included in integrated sponsorship packages, stadium

18 and arena signage including LED signage and virtual signage should be considered as one

19 format of advertising through sport (Mullin, Hardy, \& Sutton, 2007).

20 While advertising refers to a two-way communication process between advertiser and

21 consumer, sponsorship includes a three-way communication process among sponsor, property,

22 and consumer (Cameron, 2009). Accordingly, sponsorship is defined as "a business

23 relationship between a provider [sponsor] of funds, resources or services and an individual,

24 event or organisation [property] which offers in return some rights and association that may

25 be used for commercial advantage" (Sleight, 1989, p. 4). Sport sponsorship may represent the 
1 form of attaining the right of entitlement to events (e.g., Virgin Money London Marathon),

2 athletes (e.g., Adidas's endorsement deal with football celebrity David Beckham) or a facility

3 (e.g., Etihad Stadium). Through sporting events, people are exposed to a variety of marketing

4 strategies and corporate brand names or logos simply by watching the sporting actions. The

5 important point in distinguishing sponsorship from advertising is that a consumer receives a

6 sponsor's message through the property in a "passion" mode; however, a consumer receives

7 an advertiser's message through the media in an "interruption" mode (Cameron, 2009, p. 134). With this conceptual difference, a prevailing assumption is that consumers' attitude

9 towards advertising is less favourable as it appears in highly commercialised contexts (cf.

10 Meenaghan, 2001a). However, a more recent research in the sport context (Pyun et al., 2012)

11 reported that consumers' attitude towards advertising through sport was rather positive, unlike

12 other traditional adverting mediums such as television, print, and online. Yet, Pyun and his

13 colleagues (2012) failed to examine the reactions consumers had of both advertising and

14 sponsorship for direct comparison. The current study was motivated with this theoretical

15 rationale that consumers' attitudes towards advertising and sponsorship are both favourable

16 in the sport context (c.f., Pyun et al., 2012).

17 However, there has been little attempt to investigate causal mechanisms of consumers'

18 attitude formations surrounding the two domains. A better understanding of different cognitive

19 structure embedded in advertising and sponsorship enables marketers to create more effective

20 promotional strategies. For example, one football club fan feels annoyed with a certain

21 brand's flashing LED signage during the matches, and this could be a main reason s/he

22 dislikes this brand and does not want to purchase its products. Another fan is quite favourable

23 towards the club's shirt sponsor and wants to purchase the sponsor's products as s/he

24 perceives that these sponsors help boost the financial viability of their teams. The marketers

25 can develop strategies in a manner consistent with the positive belief and avoiding activating 
1 the negative stimuli. The ultimate goal of sport marketers is to increase brand images and

2 sales. A recognition of relationships among consumers' beliefs, attitudes and purchase

3 intentions will enable them to achieve this goal. This proposition is grounded on the

4 Fishbein's (1967) concept that attitude is characterised as a consequence of belief and at the

5 same time a determinant of purchase intentions.

6 Therefore, the purposes of this study were to (a) compare consumers' attitudes

7 towards advertising and sponsorship in sport and (b) empirically examine the antecedents

8 (beliefs) and the consequence (purchase intentions) of attitude towards both advertising and

9 sponsorship. This systematic research aims to provide important information to sport

10 marketers seeking to increase revenue and the enhancement of their brand image by

11 understanding how consumers think, feel, and behave.

\section{Theoretical Background}

\section{Conventional Approach to Advertising and Sponsorship}

14 Past marketing research reported that consumers' reaction to sponsorship was different from 15 advertising (e.g., Carrillat \& d'Astous, 2012; Carrillat \& d'Astous, 2013; Grohs \& Reisinger, 16 2014; Hoek, Gendall, Jeffcoat, \& Orsman, 1997). According to the classic sponsorship concept 17 (Meenaghan, 2001a), companies often considered sponsorship as a tool to pursue charitable or philanthropic activities which were deemed as beneficial to our society (e.g., linking sponsorship with corporate social responsibility). Uhrich, Koenigstorfer, and Groeppel-Klein

20 (2014) highlighted that many companies were engaged in leveraging sponsorship activities in 21 conjunction with corporate social responsibility. Given this, a key factor distinguishing sponsorship from advertising was "goodwill” generation (Meenaghan, 2001a, p. 197).

23 Meenaghan (2001a) suggested that goodwill was a key indicator of companies' investment

24 behaviour, which lowered a consumer's defense mechanism, resulting in sponsorship being 25 more acceptable. Similarly, Easton and Mackie (1998, p. 105) supported this notion that 
1 sponsorship is usually considered "more altruistic and evident of the company's social

2 conscience" than advertising. In addition, Hoek et al. (1997) provided empirical evidence that

3 sponsorship was more effective in terms of brand awareness and could produce stronger

4 associations with a wider range of a sponsor's brand attributes. Therefore, sponsorship was

5 traditionally deemed as a more effective promotional tool for a company when brand image

6 enhancement was necessary.

In contrast, advertising was seen as being more "selfish" and in the commercial interest

8 of the advertiser (Meenaghan, 2001b, p. 101). It could be more "forceful and coercive", leading

9 to an alerted state in consumers' mind to defend against such communications (Meenaghan,

102001 b, p. 101). This was a common finding from the marketing literature that consumers'

11 overall attitudes towards advertising in general and other traditional advertising mediums (e.g.,

12 TV, online, print) was getting more aggravated (e.g., Burns, 2003; Mehta, 2000; Mittal, 1994).

\section{Advertising and Sponsorship in Sport}

14 Specific to sport contexts, it was similarly claimed that consumers' attitude towards

15 sponsorship was more favourable when compared to advertising through sport (Lardinoit \&

16 Quester, 2001). While sponsorship through philanthropic activities is still popular in sport

17 (Demir \& Söderman, 2015), it is also true that sponsorship activities in the contemporary

18 professional sport and mega sport events are more commercialised with specific financial

19 goals. Given this, the findings from Lardinoit and Quester (2001) could be explained by the

20 concept of fan loyalty, where sport marketers leverage sponsorship in a way that taps into

21 fans' loyalty. When fans have strong loyalty to a sport team or event, they tend to have

22 positive attitudes towards its sponsors associated with their favourite team or event (Biscaia,

23 Correia, Rosado, Ross, \& Maroco, 2013). This is because of the image transfer process which

24 is particularly strong in sport sponsorship (Levin \& Dalakas, 2005). 
$1 \quad$ However, a different finding has been reported for advertising through sport (Pyun \&

2 James, 2010). Unlike the classical view that young and highly educated consumers usually

3 form scepticism towards traditional adverting (e.g., Schlosser, Shavitt, \& Kanfer, 1999), Pyun

4 and James (2010) revealed that American college students showed favourable attitude towards

5 advertising through sport. This finding was supported by further studies (Popović, Jakšić,

6 Matić, Bjelica, \& Maksimović, 2015; Pyun et al., 2012) that young consumers' attitude

7 towards advertising through sport was significantly more positive than their attitude towards

8 advertising in general and other traditional advertising mediums (e.g., TV commercials and

9 online advertising). While the college student samples may express aversion to traditional

10 advertising mediums, their active involvement with sport could cause them to build more

11 favourable attitudes towards advertising through sport, which can be also explained by the 12 image transfer process (Levin \& Dalakas, 2005).

13 Accordingly, it was assumed that sport consumers would perceive both sponsorship and 14 advertising in a positive way, particularly in the sport context. However, no direct comparison

15 between consumers' attitudes towards sponsorship and advertising in sport has been examined.

16 The paucity of empirical evidence in evaluating consumers' attitudes towards sport sponsorship

17 and sport advertising may lead sport marketers to erroneous decisions when selecting a

18 promotional tool. In addition, most past literature in this area (e.g., Bennett, Ferreira, Tsuji,

19 Siders, \& Cianfrone, 2006; Kim, Ko, \& James, 2011; Pyun \& James, 2010; Pyun \& James,

20 2012) utilised college student samples. While college students are considered an important

21 consumer segment in sport industries, it seems logical to recruit more generic sport consumers

22 in order to generalise the findings. Therefore, the first aim of this study aimed to compare

23 generic consumers' attitudes towards advertising through sport with their attitudes towards

24 sport sponsorship.

\section{Relationships between Beliefs and Attitude}


1 The theoretical framework of this exploratory study is derived from the concept of Fishbein

2 (1967) that the constructs of belief, attitude, and behaviour should be distinct. This multi-

3 dimensional concept considers belief as an antecedent and behaviour as a consequence of

4 attitude, forming a cognition-affection-conation relationship (Fishbein, 1967). People may

5 have different reasons for the formation of the same attitude towards a certain object. For

6 example, an English Premier League fan may form a negative attitude towards a sponsor

7 because it makes football more commercialised. Another fan may also have the same

8 negative attitude towards the sponsor because of annoyance with the sponsor logo when

9 watching games due to a lack of fit between the league and the sponsor. Belief can therefore

10 explain attitude. Using Fishbein's (1967) conceptual explanations, Pyun and James (2011)

11 considered sport as an independent advertising platform and further developed the theoretical

12 framework depicting the proposed relationships between seven beliefs and attitude toward

13 advertising through sport.

14 Pyun and James (2011) conceptualised seven belief dimensions including four positive

15 (i.e., product information, social role and image, hedonism/pleasure, and good for the

16 economy) and three negative (i.e., materialism, falsity/no sense, and annoyance/irritation)

17 beliefs which were hypothesised to predict attitude. Other studies have suggested that the

18 proposed beliefs were significant indicators in shaping overall attitudes towards advertising

19 in general and various specific mediums (e.g., Burns, 2003; Jin \& Lutz, 2013; Parreño, Sanz-

20 Blas, Ruiz-Mafé, \& Aldás-Manzano, 2013). Specific to sport marketing, the past literature

21 revealed the significant impacts of several positive beliefs (e.g., product information,

22 hedonism/pleasure, and good for the economy) on attitude toward advertising through sport;

23 however, the negative beliefs (e.g., annoyance/irritation, falsity/no sense, and materialism)

24 were not significant indicators of the attitude (Popović et al., 2015; Pyun \& James, 2010;

25 Pyun et al., 2012). This empirical evidence may support the hypothesis that consumers' 
1 overall attitude towards advertising through sport would be rather positive unlike the

2 traditional mediums. However, it should be also noted that these studies used college students

3 as samples. This segment may form more positive attitudes towards sport itself because of

4 their active involvement with sport and reduce their pre-existing negative beliefs (Pyun \&

5 James, 2011). Thus, further research on more generic consumers is warranted.

6 In terms of sponsorship, corporations usually seek associations with a sport property

7 partly because of the expectation that a sport event's positive image will transfer to a

8 sponsoring company's brand image when it is connected via sponsorship (Mullin et al., 2007).

9 Sponsorship engages consumers differently, by bestowing benefit on the activity, and

10 capitalising on consumers' emotional relationship (Meenaghan, 2001a). Past research

11 revealed a plethora of evidence in profiling of management processes where the focus is on

12 motivation, choices, and behaviours of sponsorship decision-makings as well as recall and

13 recognition tests as indicators of the effectiveness of sponsorship (e.g., Biscaia, Correia, Ross,

14 \& Rosado, 2014; Wakefield, Becker-Olsen, \& Cornwell, 2007). However, contrasting how

15 consumers establish their attitudes and behaviours towards sport sponsors and advertisers

16 hasn't been examined and may represent an important step to aid sport organisations in better

17 identifying partners and maximizing revenue. Building on the concept of attitude towards

18 advertising through sport (Pyun \& James, 2011), this study sought to examine the

19 relationships between the beliefs and attitude towards sport sponsorship, along with

20 advertising through sport. The followings are further explanations of the seven belief

21 dimensions supposed to predict attitude.

22 Product information. Product information was an important reason why people were

23 in favour of the two forms of sport promotion (Pyun \& James, 2011). Past literatures revealed

24 consistent findings that product information was a key variable in shaping overall attitudes

25 towards advertising in general and specific advertising mediums (e.g., Burns, 2003) and 
1 through sport (e.g., Bennett et al., 2006; Pyun \& James, 2010, 2012). Both advertising and

2 sponsorship should play the primary role of delivering information about attributes related to

3 products. For example, an ad in a sport magazine could include lengthy contents to explain

4 product benefits thoroughly. Sponsorship also provides potential opportunities for corporates to

5 showcase their unique product feature or technological innovations during sport events.

6 Consumers are motivated by the ability to acquire relevant information (e.g., features, price,

7 value, etc.) about the products to reduce purchase uncertainty (Murray, 1991). In addition,

8 such exposures to new product information could make consumers establish a connection

9 between the product and the environment where information is delivered (Pettigrew et al.,

10 2013). Thus, it was hypothesised as follows:

11 H1: There are positive relationships between product information and attitude towards sport sponsorship and advertising through sport.

Social role and image. Social role and image has been a popular advertising belief in explaining attitude in past literature (e.g., Pyun \& James, 2011; Pollay \& Mittal, 1993). This advertising function is often used by advertisers who develop a message that is designed to meet personal interests or curiosity of their target audiences. In advertising through sport, this function of advertising is often evidenced in athlete endorsements which use their fame or prestige (Pyun \& James, 2011). The trustworthiness and influences from celebrities easily provide an ideal image or lifestyle consumers want to learn. When advertising or sponsorship is able to help people build their own identities or styles, consumer may form their attitude towards it in a more positive way as follows: towards sport sponsorship and advertising through sport. 
1 2010; Pyun et al., 2012). Past studies in marketing and communication also indicated that

2 hedonism/pleasure was a significant belief, influencing attitude towards advertising in general

3 (e.g., Pollay \& Mittal, 1993) and in specific mediums (e.g., Burns, 2003; Parreño et al., 2013).

4 Consumers may hold preferences for hedonic or entertaining contents due to its thought-

5 provoking and interest-evoking characteristics. These characteristics demand invested time to

6 understand and consume the sport advertisements or sponsors, while stimulating purchase

7 considerations. On the other hand, consumers have little interest towards dull and boring

8 contents, lowering the intention of future purchase. Parreño et al. (2013) highlighted mobile

9 advertisers could enhance attitude through personalised and relevant message with

10 entertainment characteristics. If the messages of sport advertisements or sponsors are hedonic

11 and pleasurable, it increases the chance of acceptance of a particular sport promotion. Thus,

12 the presented study proposed the following relationship:

13 H3: There are positive relationships between hedonism/pleasure and attitude towards

$14 \quad$ sport sponsorship and advertising through sport.

15 Annoyance/irritation. The significant impact of annoyance/irritation on attitude

16 toward advertising in general and specific medium (e.g., Burns, 2003; Parreño et al., 2013)

17 could be extended to sport advertising or sponsorship. Annoyance/irritation would be a

18 significant reason why consumers form negative attitudes due to its interruptive nature, which

19 may affect the quality of the game that targeted consumers are watching. Some advertisements

20 may not be of any interest or relevance to the consumers at all. For example, some football

21 fans may be annoyed by the interruption from overwhelming LED signage presenting

22 moving, changing, and graphic images. A good balance in the number of messages exposed

23 to audiences would be helpful in order not to form negative evaluations for the signage.

24 However, Bennett et al. (2006) pointed out such physical signage on traditional locations

25 would be less intrusive than virtual signage exposed on prime locations. In addition, 
1 sponsorship activities (e.g., brand logos on team jerseys, entitlement, or naming rights) could

2 be intrusive and disrupt spectators to the extent that their attitudes are adversely influenced

3 while they are attending or watching sporting events. Based on the results of the previous

4 studies, the following relationship was suggested:

H4: There are negative relationships between annoyance/irritation and attitude towards sport sponsorship and advertising through sport.

7 Good for the economy. Good for the economy is also one popular functional attribute in the

8 advertising and sponsorship model (Lardinoit \& Quester, 2001; Pyun \& James, 2011). There

9 are several economic benefits expected from sport advertising and sponsorship. Firstly, active

10 consumption derived from advertising and sponsorship would help revitalise local economy.

11 For instance, the Super Bowl generated US\$300 to US\$400 million to a host city’s economy

12 (Matheson \& Baade, 2006). In addition, sport consumers are aware that events are more

13 financially viable with advertising and sponsorship activities. During sporting events, the

14 distributions of freebies and prize money are also dependent on the generosity of advertising

15 and sponsorship deals. A win-win situation would surface as both consumers and marketers

16 benefit from promotional activities, where consumers get to enjoy sponsored or advertised

17 products while companies have a greater opportunity to engage consumers' positive feelings

18 for the events. As such, consumers are being exposed to sport sponsors repeatedly, which

19 causes them to draw connections between the sport and the sponsors. This may create

20 consumers' positive reactions to the sponsors (Madrigal, 2000). Overall cash flow would

21 increase when consumers act on their purchase behaviour and the economy benefits as a

22 whole. Furthermore, if a sponsor's involvement is seen as altruistic in nature, marketers can

23 leverage on strategies that lead to commercial attributions as they complement the positive

24 impressions already created (Carrillat \& d'Astous, 2013). As a result, the following is

25 expected: 
H5: There are positive relationships between good for the economy and attitude towards sport sponsorship and advertising through sport.

Materialism. Polly and Mittal (1993, p. 102) described this materialism as "a set of belief structure that sees consumption as the route to most, if not all, satisfaction". In the current capitalistic environment of the sport industry, it is inevitable for sport to get more materialised. Among many factors that have influenced the commercialisation of sport, sponsorship would be a key factor as it is considered as one of the most rapidly growing elements of marketing in recent years (Meenaghan, McLoughlin, \& McCormack, 2013). As found in Meenaghan's (2001) qualitative research, many people agree that advertising makes them buy something that they do not really need. A growing number of advertising and sponsorship campaigns in sporting events would produce compulsive-buying tendency, and consumers perceive this tendency as a negative function of advertising and sponsorship, resulting in society becoming more materialistic (Kwak et al, 2002). Several empirical studies supported the negative relationship between materialism and attitude (e.g., Mittal, 1994; Pollay \& Mittal, 1993). This study also expects a negative relationship between materialism and attitude as follows:

H6: There are negative relationships between materialism and attitude towards sport sponsorship and advertising through sport.

Falsity/no sense. In past research, falsity/no sense was a negative indicator of attitude formation (Bennett et al., 2006; Schlosser et al., 1999; Shavitt, Lowrey, \& Haefner, 1998). Shavitt et al (1998) emphasised the indignity of advertising produced people's aversion to generic advertising. In the same vein, sport consumers may perceive that advertising or sponsorship activities could provide misleading information and sometimes be offensive. Many people also perceive that advertising is often dishonest or exaggerated (Meenaghan, 2001a). One possible example is the growth of gambling sponsorship in football. In the 2016- 
17 season of the English Premier League, there were 10 shirt sponsors from the gambling

2 companies, compared to five gambling sponsors in the 2012-3 season. The proliferation of

3 gambling sponsorship and advertising in football would generate a direct risk to young

4 people, where football is more popular among this segment of the population (Monaghan,

5 Derevensky, \& Sklar, 2008). Therefore, this study would propose the following hypothesis:

6 H7: There are negative relationships between falsity/no sense and attitude towards advertising through sport sponsorship and advertising through sport.

\section{Relationships between Attitude and Purchase Intentions}

9 In addition to the link between belief and attitude, Fishbein (1967) defined that behaviour

10 intention is independent from belief and attitude, and attitude is rather a predictor of

11 behaviour intention, completing the cognition-affect-conation sequence. Behaviour intention

12 has been considered one of the most popular indicators of both advertising and sponsorship

13 effectiveness (Crompton, 2004; Wells, Burnett, \& Moriarty, 2000). There have been various

14 studies attempting to explain consumers' intentions to behave in certain ways in advertising

15 or sponsorship such as purchase intention (e.g., Biscaia et al., 2013; Dees, Bennett, \&

16 Villegas, 2008; Kim et al., 2001), switching/complaint intention (e.g., Bush, Smith, \& Martin,

17 1999), and positive word-of-mouth intention (e.g., Alexandris, Tsaousi, \& James, 2007; Bush

18 et al., 1999). Dees et al. (2008) believed that purchase intention is linked to consumers'

19 perceived value and satisfaction and showed the significant impact of attitude on purchase

20 intentions in intercollegiate football sponsorship. Biscaia et al. (2013) also found attitude was

21 the strongest predictor of purchase intentions in professional football sponsorship. This

22 sequence also applies to advertising. Effective advertising campaigns elicited positive

23 reactions from consumers and formed a positive attitude which was directly related to

24 behavioural intentions (Bush et al., 1999). Thus, this study was extended from the Pyun and

25 James's (2011) model by including consumers' purchase intention as a consequence of 
1 attitude and applying to the sponsorship model for a direct comparison of processes in the

2 attitude formation with the advertising model.

\section{Research Participants}

7 Data for the study were obtained from sampling customers at several major shopping centres

H8: There are positive relationships between attitude and purchase intentions in sport sponsorship and advertising through sport.

\section{Method} in prime locations in Singapore. Customers from shopping centres constitute a major share of the market for many diverse products (Malhotra, 2010). Such a community intercept survey at shopping mall, sport bars, or event venue is an effective method to trace media patterns and learn information on the effectiveness of new promotional tools in sport marketing research (Sutton, Irwin, \& McGladden, 1998). Three trained research assistants distributed self-administered questionnaires to generic consumers using a mall-intercept method between March and April in 2017. A total of 324 respondents participated in the study. The willing participants were briefed about the purpose of the study and informed that there were no right or wrong answers, assured of the confidentiality of their responses, and encouraged to ask questions if necessary. The participants were also informed that they were allowed to withdraw from taking part in the study any time they choose to do so.

Four demographic characteristics, gender, age, ethnicity, and economic activity status were measured. The respondents consisted of 179 (55.2\%) males and $145(44.8 \%)$ females and ranged in age from 19 to 66 years $(M=36.00, S D=8.82) .62 .38 \%$ of the respondents were Chinese while Malay and Indian respondents had 21.9\% and 13.6\%, respectively, and the rest indicated that they were of other ethnicities. This demographic information of the samples was similar with that of the citizen population of Singapore (i.e., $76.1 \%$ for Chinese, 15.0\% for Malays, and 7.4\% for Indians; Singapore Department of Statistics, 2016). In terms 
1 of economic activity status, the highest percentage of respondents came from working full-

2 time (79.3\%), followed by working part-time (6.2\%), homemaker $(5.2 \%)$, retiree $(2.8 \%)$,

3 student (1.9\%), and national serviceman (1.5\%).

\section{Measurements}

5 The questionnaire included two sections measuring two domains: advertising through sport

6 and sport sponsorship. Each section contained 26 belief items, three attitude items, and three

7 purchase behaviour items in the respective domain. All items were designed to capture the

8 respondents' opinions about sport sponsorship and advertising through sport. This approach

9 focuses on measuring the respondents' cognitive, affective, and conative drivers surrounding

10 advertising and sponsorship in general rather than specific advertisements or sponsorships in

11 particular mediums or sport properties. However, it should be noted that the data on both

12 advertising and sponsorship were collected from the same subjects at one point in time,

13 possibly producing a common method variance bias (Podsakoff, MacKenzie, Lee, \&

14 Podsakoff, 2003).

The 26-item belief scale, measuring the seven belief dimensions about advertising and sponsorship was adapted from Pyun and James (2009). The seven belief dimensions include product information (three items), social role/image (three items), hedonic/pleasure (four items), annoyance/irritation (five items), good for the economy (three items), materialism (three items), and falsity/no sense (five items). The three items measuring attitude towards advertising through sport and sport sponsorship were adapted from Pollay and Mittal (1993)

21 and Mackenzie and Lutz (1989). All belief and attitude items were measured using a 7-point

22 Likert scale, anchored with strongly disagree (1) and strongly agree (7). Purchase intention

23 was measured by asking about the respondents' willingness to purchase and/or use products

24 and/or services, using a three item 7-point semantic differential scale (Madrigal, 2000). All

25 individual statements measuring three constructs are shown in Table 1. 


\section{Data Analysis}

2 For the preliminary analyses of the data, the Statistical Package for the Social Science (IBM

3 SPSS 22.0) was employed. Descriptive statistics were utilised to screen the data (e.g.,

4 missing values, outliers, and normality) and to measure the respondents' demographic

5 information. Cronbach's alpha and item-to-total correlation coefficients were calculated to

6 examine internal consistency of the measures.

$7 \quad$ For testing of the psychometric properties and the equivalence of the models between

8 the advertising and sponsorship groups, a two-phase analysis was conducted using Byrne's

9 (2004) procedures for a multigroup invariance test. In phase one, each advertising and

10 sponsorship model was tested using a confirmatory factor analysis (CFA) independently to

11 test the overall and internal model fits to the data. In phase two, chi-square and degree of

12 freedom values of this baseline model (Ho) whose all parameters were unconstrained were

13 computed from the simultaneous test between the two groups. These baseline values were

14 then compared with those of the four subsequently specified models: (a) a model with all

15 parameters constrained to be equal $\left(\mathrm{H}_{\mathrm{A}}\right),(\mathrm{b})$ a model with all factor loadings constrained to

16 be equal $\left(\mathrm{H}_{\mathrm{A} 1}\right)$, (c) a model with all factor variances/covariances constrained to be equal

$17\left(\mathrm{H}_{\mathrm{A} 2}\right)$, and $(\mathrm{d})$ a model with all error variances constrained to be equal $\left(\mathrm{H}_{\mathrm{A} 3}\right)$. Since these

18 partially constrained models were all nested within the baseline model, a chi-square difference

19 test can be employed for a direct model comparison. All analyses employed in the two phases

20 were carried out by LISREL 8.80.

21 For the main analyses, first a paired t-test was used to test if there was a significant

22 difference in attitude scores between advertising through sport and sport sponsorship.

23 Subsequently, structural equation modeling (SEM) was carried out to test the proposed

24 relationships among belief, attitude, and purchase intention for the both models. 


\section{Preliminary Analyses}

2 Descriptive statistics showed that there were no outliers and missing values or invalid data

3 responses. In terms of testing normality of the distribution of observed variables, each

4 observed variable was tested based on both skewness and kurtosis. Skewness and kurtosis

5 values should fall within the range of \pm 1.00 to be considered normal (Kline, 1998). For

6 advertising, skewness values ranged from -0.56 to 0.36 , and kurtosis values ranged from -0.80

7 to 1.34 . For sponsorship, the skewness values ranged from -0.53 to 0.41 , and kurtosis values

8 ranged from -0.99 to 0.95 . Apart from one advertising item's kurtosis statistic (1.34 for H1)

9 being slightly larger than 1.00 , the rest of the data satisfied the normality assumption (see

10 Table 1 for more details).

11

\section{\#\#\#Insert Table 1 near here\#\#\#}

For internal consistency of the measures, .70 alpha (Nunnally \& Bernstein, 1994) and .50 item-total correlation coefficients (Bearden, Netermeyer, \& Teel, 1989) were used as the cut-offs to determine the amount of variance due to the random errors of content heterogeneity. All items' item-to-total correlation coefficients in advertising (.60 .90 for beliefs, .74 .80 for attitudes, and .75 .83 for purchase intention) and sponsorship (.51 .87 for beliefs, .76 .84 for attitudes, and .67 .81 for purchase intention) were greater than .50, indicating all items were acceptable. The Cronbach's alpha coefficients ranged from .82 to .93 for advertising and from .86 to .93 for sponsorship (see Table 1).

\section{Assessments of the Measurement Model}

In phase one, two separate CFAs were performed to confirm overall goodness-of-fit, reliability, and validity of the measures utilised in both advertising and sponsorship measurement model. The global model fit tests showed the overall adequacy of the models: $\chi^{2}(428)=1534.92, \chi^{2} / d f=3.59, \mathrm{RMSEA}=.09, \mathrm{IFI}=.93, \mathrm{CFI}=.93$ for the advertising measurement model and $\chi^{2}(428)=1510.90, \chi^{2} / d f=3.53$, RMSEA $=.09$, IFI $=.94$, CFI $=.95$ 
1 for the sponsorship measurement model. The psychometric properties of the constructs were

2 measured by composite reliability, convergent validity, and discriminant validity. Table 2

3 shows the composite reliability values ranged from .82 to .93 for advertising and from .87

4 to .92 for sponsorship, satisfying its suggested values of .60 (Bagozzi \& Yi, 1988). With

5 regard to convergent validity, the AVE values ranged from .55 to .82 for advertising and

6 from .58 to .77 for sponsorship, all meeting the .50 cut-off suggested by Fornell and Larcker

7 (1981). However, eight items (H4, A3, A4, A5, M3, F3, F4 and F5) in the advertising model

8 and five items (A3, M3, and F1) in the sponsorship model failed to meet the .707 cut-off,

9 indicating that those items had more unique variance than common variance (Kline, 1998;

10 see Table 2). For testing of discriminant validity, the correlation coefficients among the belief,

11 attitude, and purchase intention constructs (see Table 3) and their AVE scores (see Table 2)

12 were used to determine if the conceptually different constructs were also supported by

13 empirical evidence (Fornell \& Larcker, 1981). The results showed that the squared

14 correlations among the constructs (.00 to .62 for advertising and .01 to .42 for sponsorship)

15 were less than their related AVE values. Thus, the constructs in both models seemed to

16 discriminate. Given the results from the CFAs, the adequacy of the model was deemed

17 appropriate for both the advertising and sponsorship models. Accordingly, the current

18 measurement was used as a baseline model for the phase two of the model invariance test.

\#\#\#Insert Table 3 near here\#\#\#

In phase two of testing for model invariance, a test for goodness-of-fit of the unconstrained baseline model (Ho) was conducted between the advertising and sponsorship

23 groups simultaneously. The null model showed an acceptable fit to the both groups: $\chi^{2}(856)=$ $243045.83 ; \mathrm{RMSEA}=.09, \mathrm{IFI}=.94, \mathrm{CFI}=.94$. The chi-square and degree of freedom values $25\left(\chi^{2}=3045.83\right.$ with $\left.d f=856\right)$ served as baseline values against the four specified models. All 
1 results related to testing for model invariance were reported in Table 4. First, we compared

2 the values $\left(\chi^{2}=3237.23\right.$ with $\left.d f=956\right)$ from the fully constrained model $\left(\mathrm{H}_{\mathrm{A}}\right)$ with those

3 from the baseline model (Ho) and rejected the null hypothesis of equality of all parameters

4 between the two groups $\left(\Delta \chi^{2}=191.40\right.$ with $\left.\Delta d f=100\right)$ at $p=.01$. It indicated that there were

5 certain variant parameter(s) somewhere in the model between the groups. We moved to the

6 next step for further investigations. We tested the second specified model $\left(\mathrm{H}_{\mathrm{A} 1}\right)$ whose all

7 factor loadings were constrained to be identical between the groups and computed a chi-

8 square statistic $\left(\chi^{2}=3131.55\right.$ with $\left.d f=888\right)$. A chi-square difference test revealed that a chi-

9 squares difference value $\left(\Delta \chi^{2}=85.72\right.$ with $\left.\Delta d f=32\right)$ was greater than its critical value of

1053.49 , also showing statistical significance. Next, the third specified model $\left(\mathrm{H}_{\mathrm{A} 2}\right)$ whose all

11 factor covariances and variances were constrained to be identical between the groups $\left(\chi^{2}=\right.$

123104.21 with $d f=892$ ) was compared with the baseline model. A chi-square difference test

13 revealed no statistical significance $\left(\Delta \chi^{2}=58.38\right.$ with $\left.\Delta d f=36\right)$. Lastly, a chi-square

14 difference test with the fourth specified model $\left(\mathrm{H}_{\mathrm{A} 3}\right)$ whose all error variances were

15 constrained to be equal between the groups and also yielded that a chi-square difference

16 value of 47.42 with 32 degrees of freedom was not statistically significant (see Table 4 for

17 more details). Overall, while a series of the model invariance tests empirically supported the

18 invariance of (co)variances and error variances in the model, the equivalence of the factor

19 loadings was questioned. However, the two nested models showed no decrease in CFI (.94

20 for the unconstrained model and .94 for the factor-constrained model; see Table 4),

21 supporting metric invariance, based on the CFI change of less than .01 (Cheung \& Rensvold, 22 2002).

23 Prior to the main tests, we refined the belief scale by removing several problematic

24 items identified from the CFAs, which were two items (A3 and A5) in annoyance/irritation

25 and two items (F1 and F5) in falsity/no sense, while retaining at least three items per 
1 dimension (see Table 2). After the item reductions, metric (factor loadings) invariance was

2 reassessed. Unfortunately, a chi-squire different test revealed still statistical significance $\left(\Delta \chi^{2}\right.$

$3=75.58$ with $\Delta d f=28)$. However, there was no decrease in CFI ( .96 for the unconstrained

4 model and .96 for the factor-constrained model). The results showed that while some factor

5 loadings seemed non-invariant, the other subsets of all parameters (factor co/variance and

6 error variance) were invariant. Milfont and Fischer (2010) noted that "full measurement

7 invariance is unlikelihood to hold in practice...too strict and unrealistic..." (p. 117). Thus, the

8 partial measurement invariance was achieved prior to the subsequent analysis (Byrne,

9 Shavelson, \& Muthén, 1989).

\section{Attitudes towards Advertising through Sport vs Sport Sponsorship}

12 A paired-sample $t$-test was conducted to test whether consumers' advertising attitude was 13 significantly different from their sponsorship attitude. The test revealed that there was no 14 significant difference between attitude towards advertising $(M=4.60, S D=0.89)$ and 15 sponsorship $(M=4.68, S D=0.97)$ at the .05 probability level: $t(323)=-1.436, p=.152$. This

16 result suggested that consumers' attitude towards advertising was not significantly lower than 17 attitude towards sponsorship in sport contexts.

\section{Assessments of the Structural Model}

19 Two structural model tests were carried out to determine if there were any different beliefs

20 dimensions in predicting attitudes in advertising and sponsorship and if an attitude was a

21 significant predictor of purchase intentions in both advertising and sponsorship. The

22 parameter estimates for the proposed relationships among beliefs, attitude, and purchase

23 intentions in the models are presented in Figure 1. The advertising model showed improved

24 model fit to the data after the model refinement: $\chi^{2}(321)=874.75, \chi^{2} / d f=3.59$, RMSEA

$25=.07, \mathrm{IFI}=.96, \mathrm{CFI}=.96$. The path analysis showed that product information $(\beta=.32, t=$ 
$15.24)$, hedonism/pleasure $(\beta=.21, t=3.32)$, and good for the economy $(\beta=.20, t=3.82)$

2 were positively related with attitude while only falsity/no sense $(\beta=-.23, t=-4.28)$ was

3 negatively related with attitude. In the sponsorship model, similar results were evidenced.

4 The sponsorship model also provided a satisfactory fit to the data: $\chi^{2}(321)=965.37, \chi^{2} / d f=$

$53.01, \mathrm{RMSEA}=.08, \mathrm{IFI}=.96, \mathrm{CFI}=.96$. The significant determinants of attitude toward

6 sport sponsorship were product information $(\beta=.36, t=5.92)$, hedonism/pleasure $(\beta=.36, t=$

7 5.90), and falsity/no sense $(\beta=-.33, t=-6.18)$. However, good for the economy $(\beta=.07, t=$

8 1.78) was no longer significant in the sponsorship model. The other one positive belief

9 (social role and image) and two negative beliefs (annoyance/irritation and materialism) were

10 not statistically significant in both models (see Figure 1). Therefore, the path analyses

11 supported H1, H3, and H7 for both models and H5 for the advertising model only. However,

12 the analyses failed to support $\mathrm{H} 2, \mathrm{H} 4$, and $\mathrm{H} 6$ for both models and H5 for the sponsorship

13 model only. The proportions of variance in the attitude constructs in both models seemed to

14 be well explained by the proposed relationships $\left(R^{2}=.53\right.$ in the advertising model and $R^{2}$

$15=.64$ in the sponsorship model). In addition, attitude was a significant indicator of purchase

16 intentions in both models: $\beta=.82, t=13.70$ for advertising $\left(R^{2}=.67\right)$ and $\beta=.69, t=11.22$

17 for sponsorship $\left(R^{2}=.48\right)$, supporting H8. Lastly, invariance of the path coefficients of the

18 relationships across both models was tested using a chi-square difference test at $p=.01\left(\chi^{2}[1]\right.$

$19=6.64)$. The three significant path coefficients of production information $\left(\Delta \chi^{2}[1]=.04\right)$,

20 hedonism/pleasure $\left(\Delta \chi^{2}[1]=.04\right)$, and Falsity/no sense $\left(\Delta \chi^{2}[1]=.38\right)$ were consistent across

21 both models. However, the path coefficients between attitude and purchase intentions were

22 non-invariant $\left(\Delta \chi^{2}[1]=22.63\right)$, indicating that the path parameter of $\beta=.82$ in advertising

23 was significantly higher than $\beta=.69$ in sponsorship. 
1 Consumers may hold different beliefs when experiencing a certain brand and then form

2 different attitudes which are an important determinant of their future behaviour towards the

3 brand (Till \& Busler, 2000). In the same manner, it is proposed that consumers perceive

4 different functions about advertising through sport or sport sponsorship and build a certain

5 attitude towards it, which eventually determines a decision to purchase a particular advertised

6 or sponsored product (Pyun \& James, 2011). On the basis of the recent empirical evidence

7 (Pyun \& James, 2012), this research started with the proposition that consumers' attitude

8 towards advertising through sport might not be that negative compared to attitude towards

9 sport sponsorship. The research extended the existing knowledge on advertising and

10 sponsorship processes by seeking to compare advertising through sport and sport sponsorship

11 in terms of consumers' attitudes and see why consumers feel in certain ways towards both communications and if there were any different beliefs significantly involved in forming the attitudes, which might be translated into their behaviour.

The results revealed that consumers' attitudes towards advertising through sport and sport sponsorship were both positive, and there was no significant difference in two mean scores. Given the previous findings that sponsorship in general tends to be more favourable than advertising in general (Carrillat \& d'Astous, 2012; Meenaghan, 2001a), this finding appears surprising. The result concerning respondents' marginally favourable reactions to sport advertising $(M=4.60)$ is inconsistent with previous studies on advertising in general (e.g., Burns, 2003; Mittal, 1994) and in specific mediums (Burns, 2003; Mittal, 1994).

21 However, this result is consistent with studies in sport contexts (e.g., Pyun \& James, 2010, 22 2012). Earlier studies conducted in the 1980s (Andrews, 1989) indicated that consumers' 23 attitude towards advertising became more negative as compared to studies done much earlier 24 in the 1950s and 1960s (Bauer \& Greyser, 1968). Research undertaken in the 2000s on 25 television or mobile advertisements also found that consumers' attitudes towards advertising 
1 in specific mediums were unfavourable, even more so than advertising in general (Mehta,

2 2000; Watson, McCarthy, \& Rowley, 2013). Likewise, consumers' attitudes towards online

3 advertisements were also unfavourable (e.g., Tan \& Chia, 2007). Similarly, Kim et al. (2011)

4 addressed that sponsorship generating a low defense mechanism among consumers would be

5 a more effective communication tool than advertising even in sport settings, following

6 Meenaghan (2001a)'s concepts. However, it was evidenced in this study that there were

7 generally favourable responses among consumers when marketers use sport as an advertising

8 platform. As for sport sponsorship, the result that consumers' attitude towards sponsorship

9 was usually favourable was consistent with past literature (e.g., Koenigstorfer \& Groeppel-

10 Klein, 2012), which is also extended by the current analysis. This finding provides marketers

11 with one important implication when deciding a promotional tool. Whether corporate

12 messages could effectively reach their consumers often depends on selection of a

13 promotional tool (Wells et al., 2000). Consumers' favourable attitudes towards advertising

14 and sponsorship imply that they are more willing to receive the messages delivered.

15 One possible explanation on why advertising and sponsorship in sport saw similar and

16 favourable attitudes from the respondents may be because of the recent fever about sport and

17 sporting events in Singapore. Singapore successfully hosted the first ever night time race in

18 the F1 Grand Prix beginning in 2008, the inaugural Youth Olympic Games in 2010, and the

19 South East Asian Games in 2015. In 2016, Singapore won its first-ever Olympic gold medal

20 in the men's 100-meter butterfly at the Rio Olympics. The hosting of major sporting events

21 and the achievements in international competitions brought pride to its citizens (Leng, Kuo,

22 Baysa-Pee, \& Tay, 2014). As such, sport provides "very strong image, has a mass

23 international audience, and appeals to all classes" (Gwinner \& Swanson, 2003, p. 275). Thus,

24 sport as an advertising or sponsorship platform would generate "excitement" and "emotional

25 attachment" among people (Copeland, Frisby, \& McCaville, 1996, p. 33). This familiarity 
1 and connection to sport or sport celebrities may overcome any initial aversions that

2 consumers have towards any form of sport advertisements or sponsorships (Pyun \& James,

3 2011). Dhurup (2014) highlighted that celebrities who have attractive features may add value

4 to an endorsed product. Thus, consumers would be more receptive to marketing using sport

5 contents. Consumers' positive attitudes towards sport promotions would explain why many

6 corporate marketers seeking a more healthy and dynamic image have turned to the use of

$7 \quad$ sport as a marketing communication tool.

Another possibility is related to the measurement. The absence of difference may be

9 explained by the format of questions asking the subjects' overall attitude towards advertising

10 and sponsorship, without referring to specific advertisers or sponsors. The consideration of

11 industry-specific advertisers and/or sponsors may have produced different results. For

12 example, with the hypothesis that consumers may form varying attitudes and purchase

13 intentions towards different sponsors, Biscaia et al. (2013) tested how consumers' attitudes

14 towards the actual specific sponsors influenced their purchase intentions of these sponsors,

15 rather than focusing on evaluation of abstract sponsorship. This issue is further discussed in

16 the limitation section below.

17 It should not be overlooked that consumers may have difficulties in distinguishing

18 advertisers from sponsors particularly in mega sport contexts. Some advertisements (e.g., in-

19 stadium signage) would be perceived as sponsorship activities among consumers, seen as

20 "feelgood" (Olson, 2010, p. 188). Olson (2010) pointed out that while people tended to

21 perceive sponsorship as less commercial communication platforms, this "feelgood" could be

22 mitigated when sponsors were believed as insincere (e.g., advertiser). The contrary concept is

23 applied for this case, enabling advertisers to capitalise on positive aspects of sponsorship (e.g.,

24 sincerity, receptivity) which would eventually rub off on their advertised brands. 
An identification of what perceptions or beliefs determine favourable attitudes

2 provides significant implications for sport marketers by underpinning consumers' cognitive

3 structures in determining their decision-making process. Thus, the next phase was designed

4 to test whether such positive elements of consumers' cognitive structures embedded in sport

5 contents worked to form attitude in a favourable way. In addition, the study sought to examine

6 the differences in the magnitudes of structural paths to see if the belief-attitude and attitude-

7 purchase intention relationships in advertising differed from those in sponsorship. Four

8 positive (product information, social role and image, hedonism/pleasure, and good for the

9 economy) and three negative beliefs (annoyance/irritation, materialism, and falsity/no sense)

10 were prepared to test the relationships with attitudes. These beliefs are believed to explain an

11 individual's attitude towards advertising through sport and sport sponsorship based on the

12 Fishbein's (1967) conceptual framework. These seven belief dimensions were measured using

13 the scale developed by Pyun and James (2009), and their relationships with attitude as well as

14 the relationship between attitude and purchase intention were tested for sponsorship and

15 advertising independently. The study provided empirical evidence that among the positive

16 belief constructs, product information, hedonism/pleasure, and good for the economy were

17 significant determinants in shaping overall attitudes in the advertising model. For the

18 sponsorship model, production information and hedonism/pleasures were significant indicators

19 of attitudes. However, good for the economy was no longer significant in the sponsorship

20 model. Interestingly, among the negative belief constructs, falsity/no sense was a negative

21 determinant for both advertising and sponsorship.

22 It was also supported that purchase intention was a significant consequence of

23 attitudes in both models (Bush et al., 1999), supporting that the existing advertising model

24 can be extended to sponsorship. The identification of key predictors of attitudes will enable

25 practitioners to create and design promotional campaigns by enhancing positive functions and 
1 at the same time reducing negative functions surrounding advertising or sponsorship. It should

2 be noted that the invariance test revealed the attitude-purchase intention link in advertising $(\beta$

$3=.82)$ was statistically stronger than that in sponsorship $(\beta=.69)$. While sponsorship is

4 deemed a more indirect/disguised attempt to persuade, advertising is very direct with greater

5 overt intent to persuade consumes (Meenaghan, 2001a). This study also revealed no

6 significant difference in the respondents' attitudes between advertising and sponsorship,

$7 \quad$ indicating both were somewhat positive, unlike the traditional belief. When combing

8 consumers' favourable attitude towards advertising with this disposition of adverting

9 (Meenaghan, 2001a), it seems the impact of attitude on purchase intention is more prominent 10 in the advertising context.

11 Consumers may form their own perceptions about the advertisements or sponsorship

12 activities. Based on the established perceptions, they build certain feelings or emotions. Then,

13 they make a decision at some point as to whether they will purchase the advertised product or

14 not. This sequence of cognition-affection-conation is what sport marketers are keen to learn

15 when planning promotional campaigns as it is an important source of competitive advantage

16 for them. For the effective advertising and sponsorship development, marketers may

17 emphasise to utilise such positive functions (e.g., promotion information, hedonism/pleasure,

18 and good for the economy) to generate positive attitudes but avoid the negative function of

19 falsity/no sense when designing promotional contents. This may show the psychological

20 process of how advertising and sponsorship work. Sport marketers in pursuing greater

21 marketplace efficiencies seem to design promotional campaigns containing production

22 information as consumers are able to better link their needs and wants to the marketers'

23 offerings (Pollay \& Mittals, 1993). The marketers also need to consider hedonism/pleasure

24 elements as a crucial technique to promote their target consumers' likability. Pyun and James

25 (2012) highlighted entertaining elements such as humour, funny message, and dramatic sport 
1 moments can easily attract consumers' attentions. More hedonic atmosphere would be far more

2 conductive to generate positive feelings among consumers. These favourable feelings are in

3 turn significant determinants of product evaluations and purchase decisions (Bush et al., 1999).

To conclude, marketing through sport remains one of the most effective ways to

5 achieve companies' marketing strategy due to the surge in sporting activities in the global

6 sport industry (Ellert, Schafmeister, Mueller, Dallwig, \& Phelan, 2014). Sport marketers have

7 considered sport sponsorship and advertising through sport as effective communication tools.

8 It has been suggested by Dean (1999) that advertising and sponsorship are two forms of

9 promotions that are best-intertwined. That implies, advertising is often included in

10 sponsorship activity particularly at mega sporting events. For example, Kinney and McDaniel

11 (1996) highlighted that "corporate sponsorship of the Olympics is frequently supported with

12 advertising touting the sponsorship" (p. 251). However, there have been many attempts to

13 distinguish between advertising and sponsorship conceptually. Meenaghan (2001a) noted that

14 advertising is a more straight forward and less vague promotional tool, and McDonald (1991)

15 defined sponsorship as "advertising plus", purporting "more than advertising" (p. 35). With

16 the proposition that advertising and sponsorship are distinct concepts as addressed by several

17 researchers (e.g., Hoek et al., 1997; Meenaghan, 2001a; Pyun \& James, 2011), the study

18 contributes to the understanding of not only consumers' reaction to both advertising and

19 sponsorship but also their cognitive outcomes that would help determine their future

20 behaviour. This study highlights consumers' attitudes towards the two promotion strategies

21 independently on the basis of different functions, utilising four positive and three negative

22 belief dimensions. The findings of this study are worthwhile, highlighting that consumers

23 generally have a more positive attitude towards sport promotions either through advertising

24 or sponsorship. It is believed that sport plays an important role to engage consumers positively

25 and have contributed to respondents' relatively more positive attitudes towards sport as a 
1 marketing tool. The relationship between attitude and purchase intention was also well

2 evidenced in both models. Developing a positive image transfer through the use of sport as a

3 marketing platform would result in an increase in purchase intention of sponsored and

4 advertised products. The findings of the study provide a better understanding as to what

5 interests and evokes consumers, providing a guide for marketing practices.

\section{$6 \quad$ Limitations and Directions for Future Research}

7 The first limitation is related with the sample utilised. Although this research contributes to

8 the existing literature on advertising and sponsorship in sport by recruiting general consumers,

9 the findings may not provide bespoke information to specific consumer segments which are

10 more homogeneous. Future research could replicate the current model with other highly

11 selective consumer segments (e.g., professionals, householders, baby boomers, etc.) to establish the external validity of the results and help marketers design promotional campaigns to effectively reach to their specific market segments. measure consumers' overall responses to sport advertising and sponsorship. However,

16 because the study did not focus on specific advertisers or sponsors, the participants may not correctly understand the difference between advertising and sponsorship (Biscaia et al., 2013). Thus, people may tend to react differently to different advertisers' or sponsors' brands linked to different sport properties due to their own perceptions of the brands and existing

20 knowledge of the sport involved (Roy \& Cornwell, 2004). According to the elaboration

21 likelihood model (see Petty, Cacioppo, \& Shumann, 1983), consumers build different decisionmaking processes on low- and high-involvement product purchase. For instance, regardless of an attitude towards a sponsor, purchase behaviour would differ between a soda (low-

24 involvement) and a car (high-involvement). Thus, future research could be designed to

25 examine specific advertisements or sponsorship activities in specific mediums (e.g., 
1 Facebook) or sport properties (e.g., UEFA Euro 2020). It would help sport marketers better

2 understand consumers' reactions to a specific advertising/sponsorship stimulus during a

3 particular exposure occasion (Lutz, 1985). In addition, controlling the level of exposure to the

4 mediums (e.g., social media) would be necessary. For instance, young people seem to watch

5 less television but spend more time on social media (Coyne, Padilla-Walker, Holmgren, \&

6 Stockdale, 2018). As such, they have different perceptions about TV commercial and online

7 advertising.

Thirdly, the current study extended the existing advertising model to sponsorship and

9 found the fairly consistent results between the two domains. The proportions of variance in

10 attitude constructs explained by the beliefs were $53 \%$ for advertising and $64 \%$ for sponsorship.

11 One possible explanation is that various advertising opportunities are sometimes packaged together with sponsorship. For instance, Man City fans can watch Etihad Airways logo in various places surrounding the stadium including players' shirts, LED displays, and stadium

14 signs. This is because the shirt sponsorship, stadium naming right, and LED signage have 15 been included in the club's one sponsorship deal. This may influence sport fans' reactions 16 towards advertising and sponsorship arbitrarily. There is thus room for improvement. For instance, Cameron (2009, p. 26) highlighted that "sponsorship works very differently than advertising" due to its three-way relationships among sponsor, property, and consumer. Due to the reason noted above, when the advertisement is presented in a sport stadium, one may argue that there is also a three-way communication process. Given that, building a proper

21 association between sponsor and property is important to achieve consumers' positive 22 responses through sponsorship (Cornwell, Weeks, \& Roy, 2005). Thus, additional bespoke

23 belief dimensions related to brand association between sponsor and property (e.g.,

24 sponsorship congruence) can be included in the sponsorship model (Rifon, Choi, Trimble, \& $25 \mathrm{Li}, 2004)$. 
1 Lastly, the current model including cognitive, affective and conative outcomes may not

2 fully explain the consumers' advertising/sponsorship communication processes. Individuals'

3 involvement with or interest in sport could be included in the model to assess a possible

4 moderation effect on the relationship between belief and attitude. Pyun and James (2011)

5 conceptualised that attitude towards sport can be a moderator of attitude toward advertising

6 through sport and highlighted that "consumers' positive attitudes towards sport may function

7 to reduce their pre-existing negative perceptions about advertising..." (p. 39). In the same

8 vein, consumers' established involvement with or interest in sport could be transferred to their

9 attitude toward advertising or sponsorship. Particularly for sponsorship model, team

10 attachment or loyalty would be a possible moderator in this linkage. A fan's attachment or

11 loyalty to a team is a key indicator of forming a favourable attitude toward sponsors

12 (Madrigal, 2000). To express loyalty to his/her favourite team, s/he would reduce his or her

13 preexisting negative perceptions about sponsorship.

14 


\section{References}

2 Alexandris, K., Tsaousi, E., \& James, J. (2007). Predicting sponsorship outcomes from attitudinal constructs: The case of a professional basketball event. Sport Marketing Quarterly, 16(3), 130-139.

5 Andrews, J. C. (1989). The dimensionality of beliefs toward advertising in general. Journal of Advertising, 18(1), 26-35.

Bauer, R. A., \& Greyser, S. A. (1968). Advertising in America: The consumer view. Boston: Harvard University Press.

Bearden, W. O., Netemeyer, R. G., \& Teel, J. E. (1989). Measurement of consumer susceptibility to interpersonal influence. Journal of Consumer Research, 15(4), 473-481.

Bennett, G., Ferreira, M., Tsuji, Y., Siders, R., \& Cianfrone, B. (2006). Analysing the effects of advertising type and antecedents on attitude towards advertising in sport. International Journal of Sports Marketing and Sponsorship, 8(1), 56-75

Biscaia, R., Correia, A., Rosado, A. F., Ross, D. S., \& Maroco, J. (2013). Sport sponsorship: The relationship between team loyalty, sponsorship awareness, attitude toward the

Biscaia, R., Correia, A., Ross, S. D., \& Rosado, A. F. (2014). Sponsorship effectiveness in professional sport: An examination of recall and recognition among football fans. International Journal of Sport Marketing and Sponsorship, 16(1), 2-18.

21 Burns, K. S. (2003). Attitude toward the online advertising format: A reexamination of the attitude toward the ad model in an online advertising context. Unpublished doctoral dissertation, University of Florida, Gainesville. 
1 Bush, A. J., Smith, R., \& Martin, C. (1999). The influence of consumer socialization variables on attitude toward advertising: A comparison of African-American and Caucasians. Journal of Advertising, 28(3), 13-24.

Byrne, B. M. (2004). Testing for multigroup invariance using AMOS: A road less traveled. Structural Equation Modeling, 11(2), 272-300.

Byrne, B. M., Shavelson, R. J., \& Muthén, B (1989). Testing for the equivalence of factor covariance and mean structures: The issues of partial measurement invariance. Psychological Bulletin, 105(3), 456-466.

Cameron, N. (2009). Understanding sponsorship and its measurement implications. Journal of Sponsorship, 2(2), 131-139.

11 Carrillat, F. A., \& d'Astous, A. (2012). The sponsorship-advertising interface: Is less better for sponsors? European Journal of Marketing, 46, 562-574.

Carrillat, F. A., \& d'Astous, A. (2013). The complementarity factor in the leveraging of sponsorship. International Journal of Sport Marketing and Sponsorship, 15(1), 1-20.

Cheung, G. W., \& Rensvold, R. B. (2002). Evaluating goodness-of-fit indexes for testing measurement invariance. Structural Equation Modeling, 9, 233-255.

Copeland, R., Frisby, W., \& McCarville, R. (1996). Understanding the sport sponsorship process form a corporate perspective. Journal of Sport Management, 10(1), 32-48.

Cornwell, T. B., Weeks, C. S., \& Roy, D. P. (2005). Sponsorship-linked marketing: Opening the black box. Journal of Advertising, 34(2), 21-42.

21 Coyne, S. M., Padilla-Walker, L. M., Holmgren, H. G., \& Stockdale, L. A. (2018). Instagrowth: A longitutidnal growth mixture model of social media time use across adolescence. Journal of Research on Adolescence. Advance online publication. doi: 10.1111/jora.12424. 
1 Crompton, J. L. (2004). Conceptualization and alternate operationalization of the measurement of sponsorship effectiveness in sport. Leisure Studies, 23, 267-281.

3 Dean, D. (1999). Brand endorsement, popularity, and event sponsorship as advertising cues affecting consumer pre-purchase attitudes. Journal of Advertising, 18, 2-12.

Dees, W., Bennett, G., \& Villegas, J. (2008). Measuring the effectiveness of sponsorship of an elite intercollegiate football program. Sport Marketing Quarterly, 17(2), 79-89.

DeGaris, L. (2015). Sports marketing: A practical approach. New York: Routledge.

Demir, R., \& Söderman, S. (2015). Strategic sponsoring in professional sport: A review and conceptualisation. European Sport Management Quarterly, 15(3), 271-300.

Dhurup, M. (2014). Sport fans and athlete celebrity endorsers: Relationships between celebrity familiarity and endorser-brand fit with brand attitude and brand purchase intentions. African Journal for Physical Health Education, Recreation and Dance, 20(4), 1537-1550.

Ellert, G., Schafmeister, G., Mueller, F., Dallwig, S., \& Phelan, S. (2014). The influence of alcohol on advertising perception and recall during a sports viewing experience. European Sport Management Quarterly, 14(2), 153-170.

Fishbein, M. (1967). A consideration of beliefs, and their role in attitude measurement. In M. Fishbein (Ed.), Readings in attitude theory and measurement. New York: John Wiley \& Sons, Inc.

Grohs, R., \& Reisinger, H. (2014). Sponsorship effects on brand image: The role of exposure and activity involvement. Journal of Business Research, 67(5), 1018-1025.

22 Gwinner, K., \& Swanson, S. R. (2003). A model of fan identification: Antecedents and sponsorship outcomes. Journal of Service Marketing, 17(3), 275-294. 
1 Harshaw, C., \& Turner, E. (1999). Assessing the recognition of perimeter advertising signage by television viewers of NASCAR Winston Cup Events. Sport Marketing Quarterly, $8(4), 35-41$.

Hoek, J., Gendall, P., Jeffcoat, M., \& Orsman, D. (1997). Sponsorship and advertising: A comparison of their effects. Journal of Marketing Communications, 3, 21-32.

Jin, H. S., \& Lutz, R. J. (2013). The typicality and accessibility of consumer attitudes toward television advertising: Implications for the measurement of attitudes toward advertising in General. Journal of Advertising, 42(4), 343-357

Kim, Y. K., Ko, Y. J., \& James, J. (2011). The impact of relationship quality on attitude toward a sponsor. Journal of Business \& Industrial Marketing, 26(8), 566-576.

11 Kinney, L., \& McDaniel, S. R. (1996). Strategic implications of attitude-toward-the-ad in leveraging event sponsorships. Journal of Sport Management, 19(3), 250-261.

Kline, R. B. (1998). Principles and practice of structural equation modeling. New York: The Guilford Press.

Koenigstorfer, J., \& Groeppel-Klein, A. (2012). Implicit and explicit attitudes to sponsors and ambushers. European Sport Management Quarterly, 12(5), 477-499.

Kwak, H., Zinkhan, G. M., \& Dominick, J. R. (2002). The moderating role of gender and compulsive buying tendencies in the cultivation effects of TV show and TV advertising: A cross cultural study between the United States and South Korea. Media Psychology, 4(1), 77-111.

21 Lardinoit, T., \& Quester, P. G (2001). Attitudinal effects of combined sponsorship and sponsor's prominence on basketball in Europe. Journal of Advertising Research, 41(1), 48-58. 
1 Leng, H. K., Kuo, T. Y., Baysa-Pee, G., \& Tay, J. (2014). Make me proud! Singapore 2010 Youth Olympic Games and its effect on national pride of young Singaporeans. International Review for the Sociology of Sport, 49(6), 745-760.

Levin, A. M., \& Dalakas, V. (2005). The balance theory domino: How sponsorship may elicit negative consumer attitudes. Advances in Consumer Research, 32, 91-97.

Lutz, R. J. (1985). Affective and cognitive antecedents of attitude toward the ad: A conceptual framework. In L. F. Alwitt \& A. A. Mitchell (Eds.), Psychological processes and advertising effects theory, research, and application. Hillsdale, NJ: Lawrence Erlbaum Associates.

Mackenzie, S. B., \& Lutz, R. J. (1989). An empirical examination of the structural antecedents of attitude toward the ad in an advertising pretesting context. Journal of Marketing, 53(2), 48-65.

Madrigal, R. (2000). The influence of social alliances with sport teams on intentions to purchase corporate sponsors' products. Journal of Advertising, 29(4), 13-24.

Malhotra, N. K. (2010). Marketing research: An applied orientation (6th ed.). Upper Saddle River, NJ: Pearson Education

Matheson, V. A., \& Baade, R. A. (2006). Padding required: Assessing the economic impact of the Super Bowl. European Sport Management Quarterly, 6(4), 353-374.

McDonald, C. (1991). Sponsorship and the image of the sponsor. European Journal of Marketing, 25(11), 31-38.

Meenaghan, T. (2001a). Sponsorship and advertising: A comparison of consumer perceptions. Psychology \& Marketing, 18(2), 191-215.

Meenaghan, T. (2001b). Understanding sponsorship effects. Psychology \& Marketing, 18(2), 95-122.

Meenaghan, T., McLoughlin, D., \& McCormack, A. (2013). New challenges in sponsorship 
evaluation actors, new media and the context of praxis. Psychology \& Marketing, 30(5), 444-460.

3 4

Mehta, A. (2000). Advertising attitudes and advertising effectiveness. Journal of Advertising Research, 67-72.

Milfont, T. L., \& Fischer, R. (2010). Testing measurement invariance across groups: Applications in cross-cultural research. International Journal of Psychological Research, 39(1), 111-121.

Mittal, B. (1994). Public assessment of TV advertising: Faint praise and harsh criticism. Journal of Advertising Research, 34(1), 35-53.

Monaghan, S., Derevensky, J., \& Sklar, A. (2008). Impact of gambling advertisements and marketing on children and adolescents: Policy recommendations to minimise harm. Journal of Gambling Issues, 22, 252-274.

Mullin, B. J., Hardy, S., \& Sutton, W. A. (2014). Sport marketing (4th ed.). Champaign, IL: Human Kinetic.

Murray, K. B. (1991). A test of services marketing theory: Consumer information acquisition activities. Journal of Marketing, 55, 10-25.

Nunnally, J. C., \& Bernstein, I. H. (1994). Psychometric theory (3rd ed.). New York: McGraw-Hill, Inc.

Olson, E. L. (2010). Does sponsorship work in the same way in different sponsorship contexts. European Journal of Marketing, 44(1/2), 180-199.

Parreño, J. M., Sanz-Blas, S., Ruiz-Mafé, C., \& Aldás-Manzano, J. (2013). Key factors of teenagers' mobile advertising acceptance. Industrial Management \& Data Systems, $113(5), 732-749$

Pettigrew, S., Rosenberg, M., Ferguson, R., Houghton, S., \& Wood, L. (2013). Game on: Do children absorb sport sponsorship message? Public Health Nutrition, 16(12), 2197-2204. 
1 Petty, R. E., Cacioppo, J. T., \& Schumann, D. (1983). Central and peripheral routes to advertising effectiveness: The moderating role of involvement. Journal of Consumer Research, 10(2), 135-146.

Pollay, R. W., \& Mittal, B. (1993). Here's the beef: Factors, determinants, and segments in consumer criticism of advertising. Journal of Marketing, 57(3), 99-114.

Podsakoff, P. M., MacKenzie, S. B., Lee, J. Y., \& Podsakoff, N. P. (2003). Common method biases in behavioral research: A critical review of the literature and recommended remedies. Journal of Applied Psychology, 88, 879-903.

Popović, S., Jakšić, D., Matić, R., Bjelica, D., \& Maksimović, N. (2015). Examining beliefs and attitudes toward advertising through sport among Serbian consumers. Studia Sportiva, 9(1), 225-231

Pyun, D. Y., \& James, J. D. (2009). Enhancing advertising communications: Developing a model of beliefs about advertising through sport. International Journal of Sport Communication, 2(1), 1-20.

Pyun, D. Y., \& James, J. D. (2010). A proposed relationship between beliefs about and attitude toward advertising through sport. International Journal of Sport Management, $11(4), 609-627$.

Pyun, D. Y., \& James, J. D. (2011). Attitude toward advertising through sport: A theoretical framework. Sport Management Review, 14(1), 33-41.

Pyun, D. Y., Kwon, H., Chon, T., \& Han, J. W. (2012). How does advertising through sport work? Evidence from college students in Singapore. European Sport Management Quarterly, 12(1), 43-63.

Rifon, N. J., Choi, S. M., Trimble, C. S., \& Li, H. (2004). Congruence effects in sponsorship: The mediating role of sponsor credibility and consumer attributions of sponsor motive. Journal of Advertising, 33(1), 30-42. 
1 Roy, D. P., \& Cornwell, T. B. (2004). The effects of consumer knowledge on responses to event sponsorships. Psychology \& Marketing, 21(3), 185-207.

3 Schwarz, E. C., Hunter, J. D., \& LaFleur, A. (2013). Advanced theory and practice in sport marketing (2nd ed.). New York: Routledge.

Schlosser, A. E., Shavitt, S., \& Kanfer, A. (1999). Survey of internet users' attitudes toward internet advertising. Journal of Interactive Marketing, 13(3), 34-54.

Shavitt, S., Lowrey, P., \& Haefner, J. (1998). Public attitude toward advertising: More favorable than you might think. Journal of Advertising Research, 37(4), 325-343.

Singapore Department of Statistics (2016). Population in brief 2016. Retrieved from https://www.nptd.gov.sg/PORTALS/0/HOMEPAGE/HIGHLIGHTS/population-inbrief-2016.pdf

Sleight, S. (1989). Sponsorship: What it is and how to use it. Berkshire, UK: McGraw-Hill.

Sutton, W. A., Irwin, R. I., \& McGladden, J. M. (1998). Tools of the trade: Practical research methods for events, teams and venues. Sport Marketing Quarterly, 7(2), 45-49.

Tan, S. J., \& Chia, L. (2007). Are we measuring the same attitude? Understanding media effects on attitude towards advertising. Marketing Theory, 7, 353-377.

Till, B., \& Busler, M. (2000). The match-up hypothesis: Physical attractiveness, expertise, and the role of fit on brand attitude, purchase intent and brand beliefs. Journal of Advertising, 29(3), 1-13.

Uhrich, S., Koenigstorfe, J, \& Groeppel-Klein, A. (2014). Leveraging sponsorship with corporate social responsibility. Journal of Business Research, 67(9), 2023-2029.

Wakefield, K. L., Becker-Olsen, K., \& Cornwell, T. B. (2007). I spy a sponsor. Journal of Advertising, 36(4), 61-74.

24 Wells, W. D., Moriarty, S., \& Burnett, J. (2005). Advertising principles and practice (7th ed.). Upper Saddle River, NJ: Prentice Hall, Inc. 
Table 1

Descriptive Statistics of the Belief and Attitude Items for Advertising through Sport (Sport Sponsorship)

\begin{tabular}{|c|c|c|c|c|c|c|}
\hline & Advertising (sponsorship) through sport... & M & SD & Skewness & Kurtosis & $\alpha$ \\
\hline \multirow{3}{*}{$\begin{array}{l}\text { Product } \\
\text { information }\end{array}$} & tells me which brands have the features I am looking for. (P1) & $4.82(4.65)$ & $1.16(1.24)$ & $-0.56(-0.29)$ & $0.32(-0.50)$ & \multirow{3}{*}{$\begin{array}{c}.82 \\
(.89)\end{array}$} \\
\hline & helps me to keep up to date about the products available in the marketplace. (P2) & $4.93(4.74)$ & $1.05(1.21)$ & $-0.42(-0.40)$ & $0.85(-0.03)$ & \\
\hline & is a good source of product information. (P3) & $4.79(4.56)$ & $1.12(1.23)$ & $-0.32(-0.16)$ & $0.32(-0.33)$ & \\
\hline \multirow{3}{*}{$\begin{array}{l}\text { Social role } \\
\text { and image }\end{array}$} & helps me learn about fashions and about what to buy to impress others. (S1) & $4.36(4.19)$ & $1.42(1.42)$ & $-0.48(-0.30)$ & $-0.22(-0.45)$ & \multirow{3}{*}{$\begin{array}{c}.87 \\
(.87)\end{array}$} \\
\hline & helps me to learn what is in fashion and what I should buy for keeping a good social image. (S2) & $4.30(4.22)$ & $1.42(1.43)$ & $-0.27(-0.17)$ & $-0.28(-0.58)$ & \\
\hline & gives me ideas about fashion. (S3) & $4.54(4.34)$ & $1.38(1.39)$ & $-0.22(-0.12)$ & $-0.52(-0.56)$ & \\
\hline \multirow{4}{*}{$\begin{array}{l}\text { Hedonism/ } \\
\text { pleasure }\end{array}$} & is often amusing and entertaining. (H1) & $4.77(4.45)$ & $1.02(1.19)$ & $-0.36(-0.08)$ & $1.34(-0.22)$ & \multirow{4}{*}{$\begin{array}{l}.89 \\
(.93)\end{array}$} \\
\hline & is enjoyable. $(\mathrm{H} 2)$ & $4.75(4.51)$ & $1.01(1.17)$ & $-0.29(-0.10)$ & $0.81(-0.01)$ & \\
\hline & gives me pleasure when I think about what I saw or heard or read. (H3) & $4.56(4.33)$ & $1.02(1.14)$ & $-0.23(-0.18)$ & $0.64(-0.03)$ & \\
\hline & is sometimes even more enjoyable than other media contents. (H4) & $4.65(4.33)$ & $1.04(1.21)$ & $-0.30(-0.19)$ & $0.88(-0.23)$ & \\
\hline \multirow{5}{*}{$\begin{array}{l}\text { Annoyance/ } \\
\text { irritation }\end{array}$} & is annoying. (A1) & $3.26(3.35)$ & $1.12(1.18)$ & $0.18(0.41)$ & $0.42(0.10)$ & \multirow{5}{*}{$\begin{array}{l}.87 \\
(.92)\end{array}$} \\
\hline & is irritating. (A2) & $3.23(3.30)$ & $1.16(1.20)$ & $0.03(0.27)$ & $0.05(-0.03)$ & \\
\hline & is too often. (A3) & $3.74(3.59)$ & $1.32(1.52)$ & $0.20(0.20)$ & $0.09(-0.55)$ & \\
\hline & is too ridiculous. (A4) & $3.50(3.58)$ & $1.24(1.49)$ & $0.36(0.33)$ & $0.21(-0.39)$ & \\
\hline & is too loud. (A5) & $3.56(3.66)$ & $1.14(1.34)$ & $0.11(0.19)$ & $-0.01(-0.15)$ & \\
\hline \multirow{3}{*}{$\begin{array}{l}\text { Good for the } \\
\text { economy }\end{array}$} & in general helps our nation's economy. (G1) & $4.23(4.39)$ & $1.02(0.95)$ & $-0.39(-0.43)$ & $0.50(0.85)$ & \multirow{3}{*}{$\begin{array}{r}.93 \\
(.91)\end{array}$} \\
\hline & generally helps the local economy. (G2) & $4.28(4.47)$ & $1.09(0.96)$ & $-0.29(-0.50)$ & $0.54(0.94)$ & \\
\hline & helps raise our standard of living. (G3) & $4.16(4.35)$ & $1.12(0.98)$ & $-0.22(-0.11)$ & $0.22(0.79)$ & \\
\hline \multirow[t]{3}{*}{ Materialism } & is making us a materialistic society, overly interested in buying and owning things. (M1) & $4.96(4.65)$ & $1.35(1.37)$ & $-0.16(0.18)$ & $-0.80(-0.87)$ & \multirow{3}{*}{$\begin{array}{l}.85 \\
(.86)\end{array}$} \\
\hline & influences people to buy things they do not really need. (M2) & $5.03(4.69)$ & $1.38(1.43)$ & $-0.40(-0.01)$ & $-0.47(-0.99)$ & \\
\hline & leads to a waste of natural resources by creating desires for unnecessary goods. (M3) & $4.49(4.28)$ & $1.46(1.47)$ & $-0.04(0.26)$ & $-0.49(-0.65)$ & \\
\hline \multirow{5}{*}{$\begin{array}{l}\text { Falsity/no } \\
\text { sense }\end{array}$} & in general is misleading. (F1) & $4.28(4.34)$ & $1.30(1.35)$ & $0.08(0.22)$ & $-0.51(-0.74)$ & \multirow{5}{*}{$\begin{array}{c}.86 \\
(.86)\end{array}$} \\
\hline & is deceptive. $(\mathrm{F} 2)$ & $4.23(4.03)$ & $1.27(1.40)$ & $0.26(0.36)$ & $-0.54(-0.33)$ & \\
\hline & is dishonest. (F3) & $3.67(3.46)$ & $1.10(1.14)$ & $0.33(0.02)$ & $0.39(0.26)$ & \\
\hline & is untrue. $(\mathrm{F} 4)$ & $3.55(3.35)$ & $1.11(1.17)$ & $0.30(0.11)$ & $0.52(0.36)$ & \\
\hline & is bad for children. (F5) & $3.57(3.46)$ & $1.29(1.36)$ & $0.28(0.11)$ & $-0.17(-0.30)$ & \\
\hline \multirow[t]{3}{*}{ Attitude } & My general opinion of advertising through sport (sport sponsorship) is favourable. (A1) & $4.51(4.60)$ & $0.90(1.00)$ & $-0.21(0.17)$ & $0.15(0.11)$ & \multirow{3}{*}{$\begin{array}{l}.88 \\
(.89)\end{array}$} \\
\hline & Overall, I consider advertising through sport (sport sponsorship) a good thing. (A2) & $4.57(4.69)$ & $0.98(1.01)$ & $0.02(0.11)$ & $0.33(0.18)$ & \\
\hline & Overall, I like advertising through sport (sport sponsorship). (A3) & $4.70(4.75)$ & $1.08(1.16)$ & $-0.15(-0.08)$ & $0.53(0.01)$ & \\
\hline \multirow{4}{*}{$\begin{array}{l}\text { Purchase } \\
\text { intention }\end{array}$} & Are you willing to buy/use products or services of companies who are utilising advertising (spons & p) through $\mathrm{s}$ & ort? & & & \multirow{4}{*}{$\begin{array}{l}.89 \\
(.86)\end{array}$} \\
\hline & Extremely unlikely - extremely likely (PI1) & $4.34(4.36)$ & $1.13(0.95)$ & $-0.33(-0.28)$ & $-0.24(0.60)$ & \\
\hline & Not probable - Probable (PI2) & $4.48(4.45)$ & $1.21(0.97)$ & $-0.47(-0.53)$ & $-0.16(0.95)$ & \\
\hline & No chance - certain chance (PI3) & $4.60(4.59)$ & $1.26(1.12)$ & $-0.36(-0.20)$ & $-0.18(0.61)$ & \\
\hline
\end{tabular}

Note 1: The sponsorship values are shown in parentheses. Note 2: Purchase intention items were measured by asking about the respondents' willingness to purchase and/or use advertised (sponsored) products and/or services. 
Table 2

Assessment of Internal Model Fit in the Measurement Model for Advertising through Sport (Sport Sponsorship)

\begin{tabular}{|c|c|c|c|c|}
\hline & & Factor loading & Composite reliability & AVE \\
\hline Product & P1 & $.73(.85)$ & $.82(.89)$ & $.61(.74)$ \\
\hline \multirow[t]{2}{*}{ information } & P2 & $.85(.90)$ & & \\
\hline & P3 & $.75(.82)$ & & \\
\hline \multirow{3}{*}{$\begin{array}{l}\text { Social role and } \\
\text { image }\end{array}$} & S1 & $.79(.82)$ & $.88(.88)$ & $.71(.72)$ \\
\hline & S2 & $.95(.94)$ & & \\
\hline & S3 & $.78(.77)$ & & \\
\hline \multirow{4}{*}{$\begin{array}{l}\text { Hedonism/ } \\
\text { pleasure }\end{array}$} & H1 & $.90(.90)$ & $.89(.92)$ & $.68(.77)$ \\
\hline & $\mathrm{H} 2$ & $.94(.93)$ & & \\
\hline & H3 & $.74(.86)$ & & \\
\hline & $\mathrm{H} 4$ & $.69(.80)$ & & \\
\hline \multirow{5}{*}{$\begin{array}{l}\text { Annoyance/ } \\
\text { irritation }\end{array}$} & A1 & $.94(.94)$ & $.87(.91)$ & $.57(.71)$ \\
\hline & A2 & $.94(.96)$ & & \\
\hline & $\mathrm{A} 3^{\mathrm{a}}$ & $.57(.68)$ & & \\
\hline & A4 & $.67(.74)$ & & \\
\hline & $\mathrm{A} 5^{\mathrm{a}}$ & $.58(.72)$ & & \\
\hline \multirow{3}{*}{$\begin{array}{l}\text { Good for the } \\
\text { economy }\end{array}$} & G1 & $.91(.87)$ & $.93(.91)$ & $.82(.77)$ \\
\hline & G2 & $.96(.96)$ & & \\
\hline & G3 & $.84(.79)$ & & \\
\hline \multirow[t]{3}{*}{ Materialism } & M1 & $.88(.80)$ & $.87(.87)$ & $.69(.70)$ \\
\hline & M2 & $.93(1.00)$ & & \\
\hline & M3 & $.65(.68)$ & & \\
\hline \multirow[t]{5}{*}{ Falsity/no sense } & $\mathrm{F} 1^{\mathrm{a}}$ & $.84(.53)$ & $.86(.87)$ & $.55(.58)$ \\
\hline & $\mathrm{F} 2$ & $.88(.74)$ & & \\
\hline & $\mathrm{F} 3$ & $.69(.88)$ & & \\
\hline & $\mathrm{F} 4$ & $.65(.84)$ & & \\
\hline & $\mathrm{F}^{\mathrm{a}}$ & $.61(.76)$ & & \\
\hline \multirow[t]{3}{*}{ Attitude } & Att1 & $.84(.90)$ & $.88(.90)$ & $.72(.75)$ \\
\hline & Att2 & $.89(.86)$ & & \\
\hline & Att3 & $.81(.84)$ & & \\
\hline & PI1 & $.82(.75)$ & $.90(.87)$ & .74(.69) \\
\hline \multirow{2}{*}{ intention } & PI2 & $.90(.90)$ & & \\
\hline & PI3 & $.86(.84)$ & & \\
\hline
\end{tabular}

${ }^{a}$ Those items were removed after the model invariance tests.

Note: The sponsorship values are shown in parentheses. 
Table 3

Correlations Coefficients among the Latent Variables for Advertising through Sport (Sport Sponsorship)

\begin{tabular}{|c|c|c|c|c|c|c|c|c|c|}
\hline & $\begin{array}{c}\text { Product } \\
\text { information }\end{array}$ & $\begin{array}{c}\text { Social role and } \\
\text { image }\end{array}$ & $\begin{array}{l}\text { Hedonism/ } \\
\text { pleasure }\end{array}$ & $\begin{array}{c}\text { Annoyance/ } \\
\text { irritation }\end{array}$ & $\begin{array}{c}\text { Good for the } \\
\text { economy }\end{array}$ & Materialism & $\begin{array}{l}\text { Falsity/ } \\
\text { no sense }\end{array}$ & Attitude & $\begin{array}{l}\text { Purchase } \\
\text { intention }\end{array}$ \\
\hline $\begin{array}{l}\text { Product } \\
\text { information }\end{array}$ & 1 & & & & & & & & \\
\hline $\begin{array}{l}\text { Social role and } \\
\text { image }\end{array}$ & $.46 *\left(.55^{*}\right)$ & 1 & & & & & & & \\
\hline $\begin{array}{l}\text { Hedonism/ } \\
\text { pleasure }\end{array}$ & $.40 *\left(.55^{*}\right)$ & $.49 *(.60 *)$ & 1 & & & & & & \\
\hline $\begin{array}{l}\text { Annoyance/ } \\
\text { irritation }\end{array}$ & $-.35^{*}\left(-.40^{*}\right)$ & $-.28 *(-.31 *)$ & $-.41 *(-.44 *)$ & 1 & & & & & \\
\hline $\begin{array}{l}\text { Good for the } \\
\text { economy }\end{array}$ & $.12(.08)$ & $.05(.09)$ & $.33 *(.14 *)$ & $-.24 *(-.10)$ & 1 & & & & \\
\hline Materialism & $.05(.20 *)$ & $.04\left(.12^{*}\right)$ & $-.20 *(.11 *)$ & $.27 *(.10)$ & $-.31 *(-.11 *)$ & 1 & & & \\
\hline $\begin{array}{l}\text { Falsity/no } \\
\text { sense }\end{array}$ & $-.21 *(-.25 *)$ & $-.10(-.11)$ & $-.19 *(-.17 *)$ & $.36 *(.49 *)$ & $-.27 *(-.13 *)$ & $.63 *(.42 *)$ & 1 & & \\
\hline Attitude & $.51 *(.62 *)$ & $.35^{*}(.37 *)$ & $.48 *(.59 *)$ & $-.42 *(-.50 *)$ & $.36 *\left(.18^{*}\right)$ & $-.27 *(.01)$ & $-.48^{*}\left(-.53^{*}\right)$ & 1 & \\
\hline $\begin{array}{l}\text { Purchase } \\
\text { intention }\end{array}$ & $.45 *(.50 *)$ & $.42 *(.54 *)$ & $.53 *(.57 *)$ & $-.37 *(-.42 *)$ & $.39 *(.25 *)$ & $-.28 *(-.08)$ & $-.40 *(-.38 *)$ & $.79 *(.65 *)$ & 1 \\
\hline
\end{tabular}

*Significant at the .05 probability level.

Note: The correlation coefficients for sponsorship were included in the parenthesis. 
Table 4

Test of Invariance of the Parameters between the Advertising and Sponsorship Models

\begin{tabular}{lcccc}
\hline & Model & $\chi^{2}(d f)$ & Test of invariance & CFI \\
\hline $\begin{array}{l}\text { Null hypothesis (Ho): All unconstrained } \\
\text { parameters }\end{array}$ & $3045.83(856)$ &. & .94 \\
\hline & All parameters $\left(\mathrm{H}_{\mathrm{A}}\right)$ & $3237.23(956)$ & $H_{A}-H o=\Delta \chi^{2}(100)=191.40^{*}$ & .93 \\
& Factor loadings $\left(\mathrm{H}_{\mathrm{A} 1}\right)$ & $3131.55(888)$ & $H_{A 1}-H o=\Delta \chi^{2}(32)=85.72^{*}$ & .94 \\
$\begin{array}{l}\text { Constrained } \\
\text { parameters }\end{array}$ & Factor co/variances $\left(\mathrm{H}_{\mathrm{A} 2}\right)$ & $3104.21(892)$ & $H_{A 2}-H o=\Delta \chi^{2}(36)=58.38$ & .94 \\
& Error variances $\left(\mathrm{H}_{\mathrm{A} 3}\right)$ & $3093.25(888)$ & $H_{A 3}-H o=\Delta \chi^{2}(32)=47.42$ & .94 \\
\hline
\end{tabular}

*Significant at the .01 probability level.

Note: The critical values of chi-square with 100,36 , and $32 d f s$ at the .01 probability level are $135.81,58.62$, and 53.49 , respectively. 


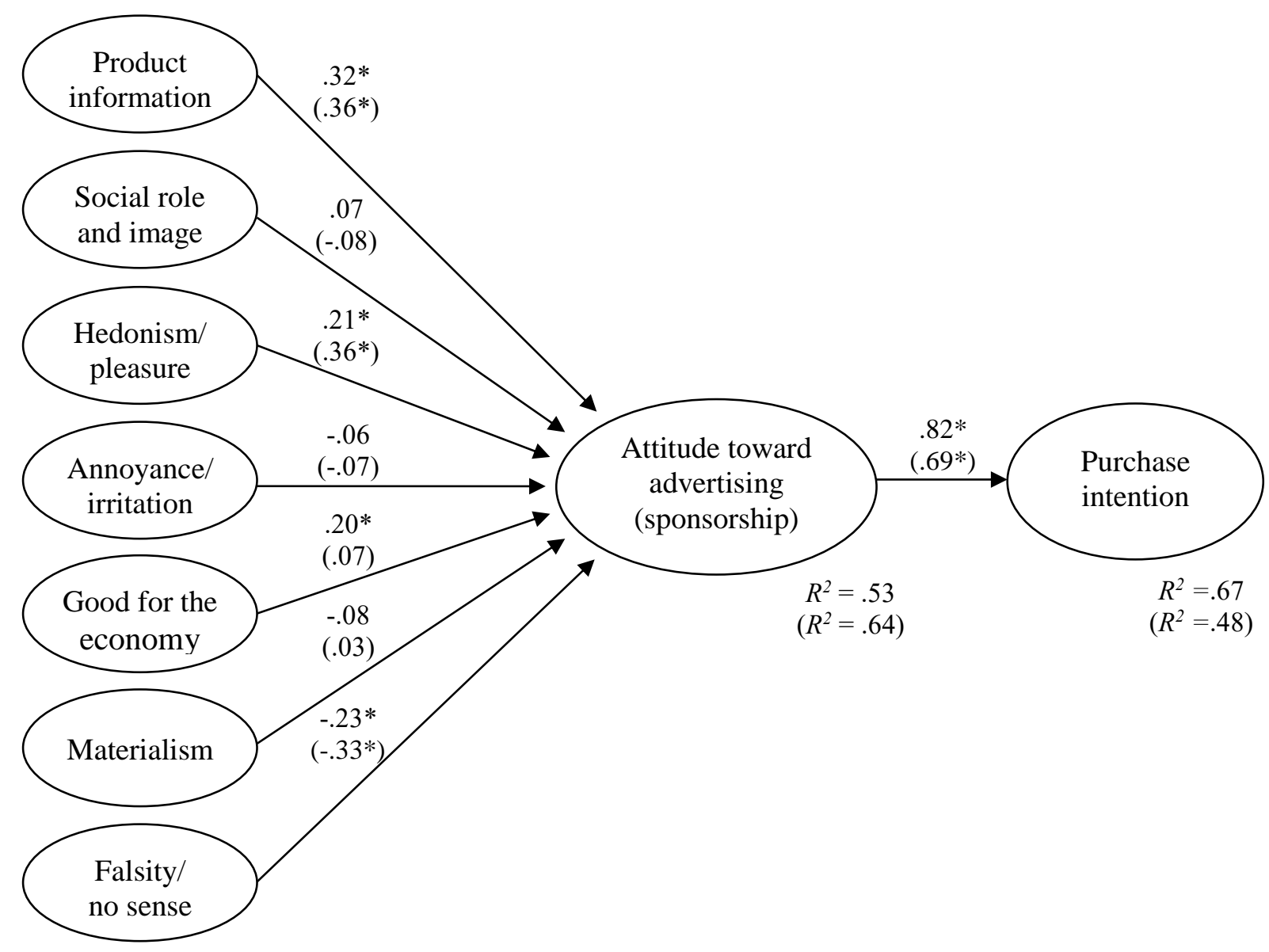

Figure 1. Standardised parameter estimates of the structural models for advertising through sport (sport sponsorship)

$*$ Significant at $\alpha=.05$.

Note: The sponsorship values are shown in parentheses. 